\title{
Risk factors for suicide in individuals with cancer: an integrative literature review
}

\author{
Fatores de risco para suicídio em indivíduos com câncer: revisão integrativa da literatura
}

Factores de riesgo de suicidio en individuos con cáncer: una revisión integradora de la literatura

Marcos Vinicius de Carvalho Mendes'
ORCID: 0000-0003-2841-9869

Solange Laurentino dos Santos' ORCID: 0000-0002-6405-3959

Albanita Gomes da Costa de Ceballos' ORCID: 0000-0002-8658-9981

Betise Mery Alencar Sousa Macau Furtado" ORCID: 0000-0001-6344-8257

Cristine Vieira do Bonfim' ORCID: 0000-0002-4495-9673

'Universidade Federal de Pernambuco. Recife, Pernambuco, Brazil.

"Universidade de Pernambuco. Recife, Pernambuco, Brazil.

How to cite this article: Mendes MVC, Santos SL, Ceballos AGC, Furtado BMASM Bonfim CV. Risk factors for suicide in individuals with cancer: an integrative literature review. Rev Bras Enferm. 2021;74(Suppl 3):e20190889. https://doi.org/10.1590/0034-7167-2019-0889

Corresponding author:

Marcos Vinicius de Carvalho Mendes E-mail:marcosvcmendes@gmail.com

EDITOR IN CHIEF: Dulce Barbosa ASSOCIATE EDITOR: Marcos Brandão

Submission: 03-01-2020 Approval: 10-31-2020

\section{ABSTRACT}

Objective: to develop an integrative literature review on risk factors for suicide in individuals with cancer. Method: searching for articles was conducted in the Scientific Electronic Library Online, Medicinal Literature Analysis and Retrieval System Online, Latin American \& Caribbean Literature in Health Sciences, Cumulative Index to Nursing and Allied Health Literature and SciVerse Scopus databases, using the descriptors "suicide" and "cancer". Results: eighteen articles were selected. Lung, bladder and colorectal cancers are the types of highest risk for suicide. Male, white and over 60 years of age are demographic factors with higher risk for suicide in individuals with cancer. Conclusion: this review made it possible to verify that cancer may be a risk factor for suicide. This evidence can be useful for planning preventive actions in order to reduce the risk of suicide.

Descriptors: Neoplasms; Suicide; Risk Factors; Review; Epidemiology.

\section{RESUMO}

Objetivo: desenvolver uma revisão integrativa de literatura sobre os fatores de risco para o suicídio nos indivíduos com câncer. Método: as buscas dos artigos foram conduzidas nas bases de dados Scientific Eletronic Library Online, Medicinal Literature Analysis and Retrieval System Online, Literatura Latino-Americana e do Caribe em Ciências da Saúde, Cumulative Index to Nursing and Allied Helth Literature e SciVerse Scopus por meio dos descritores "suicide" e"câncer". Resultados: selecionaram-se 18 artigos. Os cânceres de pulmão, bexiga e colorretal são os tipos de maior risco para o suicídio. O sexo masculino, cor branca e idade maior que 60 anos são fatores demográficos com maior risco para o suicídio em indivíduos com câncer. Conclusão: a revisão possibilitou verificar que o câncer pode ser um fator de risco para o suicídio. Essas evidências podem ser úteis para o planejamento de ações de prevenção, com o intuito de reduzir os riscos de suicídio.

Descritores: Câncer; Suicídio; Fatores de Risco; Revisão; Epidemiologia.

\section{RESUMEN}

Objetivo: desarrollar una revisión integradora de la literatura sobre factores de riesgo de suicidio en personas con cáncer. Método: las búsquedas de los artículos se realizaron en las bases de datos Scientific Electronic Electronic Library Online, Medicinal Literature Analysis and Retrieval System Online, Literatura Latinoamericana y del Caribe en Ciencias de la Salud, Cumulative Index to Nursing and Allied Helth Literature y SciVerse Scopus a través de descriptores "suicidio"y "cáncer". Resultados: se seleccionaron 18 artículos. Los cánceres de pulmón, vejiga y colorrectal son los tipos de mayor riesgo de suicidio. Los hombres, los blancos y los mayores de 60 años son factores demográficos con mayor riesgo de suicidio en personas con câncer. Conclusión: la revisión permitió verificar que el cáncer puede ser un factor de riesgo de suicidio. Esta evidencia puede ser útil para planificar acciones preventivas con el fin de reducir el riesgo de suicidio.

Descriptores: Neoplasias; Suicidio; Factores de Riesgo; Revisión; Epidemiología. 


\section{INTRODUCTION}

Suicide is considered an important public health concern in contemporary society ${ }^{(1)}$. Over 800,000 suicide deaths are estimated annually and the mortality rate is 11.4 per 100,000 people ${ }^{(2)}$. It consists of a phenomenon in which death occurs due to a behavioral act and is related to complex, universal and multifactorial issues ${ }^{(3)}$. Risks for suicide include population or individual factors ${ }^{(4)}$. Those of a population nature comprise aspects such as economic crisis and social fragmentation, while those of an individual nature include family and relationship problems, mental disorders and the use of alcohol or other drugs ${ }^{(4)}$.

Cancer represents the second leading cause of mortality in the world, with an estimated 17 million deaths in 2030 and a general proportion of one in six deaths $s^{(5)}$. It is estimated that, in the next 20 years, the total number of new cases will be 29.4 million, with a forecast of reaching 1.9 million deaths ${ }^{(6)}$. In Brazil, for the 2020-2022 biennium, there is an estimate of 450 thousand new cases for each year ${ }^{(7)}$. It is a chronic disease, capable of invading surrounding organs and tissues, and is associated with a stigma of death ${ }^{(8-9)}$. Moreover, being diagnosed with cancer can generate consequences on individuals' mental health, such as mood swings, insomnia, anxiety, and depression ${ }^{(2,45)}$.

In individuals with cancer, depression is a disorder that has a high prevalence, which affects patients' ability to deal with the disease, decreasing treatment acceptance, prolonging hospitalization, reducing quality of life and increasing the risk of suicide ${ }^{(10)}$, being a factor that is present in $75 \%$ of suicides ${ }^{(11)}$. In turn, cancer diagnosis is a serious stressor, with many physical and psychological consequences ${ }^{(12)}$, and it is believed to be a risk factor for suicide ${ }^{(10)}$. Individuals with cancer, when compared to the general population, are at twice the risk of committing suicide ${ }^{(13)}$ and studies carried out in several countries have shown an increase in suicide rates in individuals with cancer ${ }^{(14-18)}$.

A recent systematic review study on cancer diagnosis and suicide highlighted cancer as a factor to increase the suicide rate in these individuals ${ }^{(10)}$. Poor prognosis, disease progression level, symptoms of depression, feelings of helplessness, disturbing interpersonal relationships and uncontrolled pain are reasons for increased rates of suicide in individuals with cancer ${ }^{(10)}$. Depression, psychiatric history, previous suicide attempts, hopelessness, demoralization, pain, lack of social support, feeling of being a burden to others and existential concerns (regret, loss of meaning, purpose, and dignity), along with specific demographic characteristics and certain types of cancer, increase the risk of suicide ${ }^{(19)}$.

Although the absolute numbers of suicides in individuals with cancer are low, the high risk of suicide in these individuals should be a concern for health professionals, since they represent potentially preventable deaths. It is essential that cancer health professionals know how to identify suicide risk in their cancer patients; however, the understanding, assessment and recognition of risk by these professionals are limited ${ }^{(20)}$. A research conducted with oncologists, nurses and social workers reported that most nurses and oncologists had at least one patient who committed suicide. These professionals identified lack of training and awareness as main barriers for identifying patients at risk of suicide ${ }^{(20)}$. Another research, carried out with oncology nurses, showed that they were able to identify certain behavioral risk factors, but not demographic risk factors, and that most had little knowledge in assessing suicide ${ }^{(21)}$.

For integrated, early care associated with psychosocial care, it is necessary to understand the variation in the risk of suicide between sexes, age group, type of cancer and modifiable risk factors. In this regard, knowing more about suicide in the population diagnosed with cancer is essential both for health professionals who work on the front line with patients, particularly nurses, due to the possibility of previously identifying the main clinical and behavioral characteristics, as well as for managers in preventive measure implementation. The guiding question that guided this literature review was: what are the risk factors for suicide in individuals with cancer observed in articles published in the scientific literature?

\section{OBJECTIVE}

To develop an integrative literature review on risk factors for suicide in individuals with cancer.

\section{METHODS}

This is an integrative literature review. This review method synthesizes the scientific literature on a given topic, to provide a greater understanding of the leading question. Integrative reviews present the state of science, contributing to the development of theory and have direct applicability to practice and policy ${ }^{(22)}$.

This integrative literature review was carried out in stages that included theme identification; research question development; database research through health descriptors; selection of articles that have eligibility criteria; reading of selected articles; assessment and interpretation of structured data from the integrative review.

Article search was conducted in the Scientific Electronic Library Online (SciELO), Medicinal Literature Analysis and Retrieval System Online (MEDLINE), Latin American \& Caribbean Literature in Health Sciences (LILACS), Cumulative Index to Nursing and Allied Health Literature (CINAHL) and SciVerse Scopus (SCOPUS) databases. The descriptors used in the search were extracted from the list of Health Science Descriptors (DeCS - Descritores em Ciências da Saúde) and Medical Subject Headings (MeSH). The expression and descriptors applied, and combined, in all searches were "suicide and cancer". The search strategy is described in Chart 1.

Chart 1 - Database search strategy according to health descriptors

\begin{tabular}{|c|l|}
\hline Databases & Search structure \\
\hline Scielo & (cancer) OR (neoplasm) AND (suicide) OR (suicídio) \\
\hline MEDLINE & (("cancer" [Mesh] AND "suicide" [tiab])) AND surgery \\
\hline LILACS & $\begin{array}{l}\text { (mh: neoplasms OR tw: cancer*) AND (mh: suicídio OR } \\
\text { tw: suicídio* OR tw: parassuicídio*)) }\end{array}$ \\
\hline CINAHL & TI (neoplasm* OR cancer*) AND (("suicide”) \\
\hline Scopus & (TITLE (neoplasm* OR cancer*)) AND OR (TITLE (suicide*) \\
\hline
\end{tabular}

The terms should be present in the title or in the abstract. Articles in English or Portuguese, original and complete articles, published between 2014 and 2019 were included. Two researchers 
searched the articles independently and blindly. Titles and abstracts were carefully examined and the full texts of the papers that met the inclusion criteria were obtained. After this stage, the selected articles were read in full and, at the end, the researchers met to compare the search results. Disagreements among researchers were resolved by consulting a third reviewer.

Literature review studies, letters to the editor, monographs and theses were excluded. Articles that addressed only suicidal ideation, associated with cancer, without relating to suicide and articles referring to assisted suicide or euthanasia were not included. Duplicates have been removed.

The combination of descriptors used in database searches resulted in a quantity of 1,497 scientific articles. Of these, 59 articles were identified by reading the title, abstract and keywords as potential for the selection of inclusion in this integrative review, and read in full by two independent evaluating authors. After reading: nine articles aimed to study suicide attempts and did not relate risk factors to suicide; eight articles did not relate cancer and risk factors for suicide; eight did not answer the guiding question; six related suicidal ideation and attempted suicide; five were literature reviews; five were not available in full.

With the verification of the inclusion and exclusion criteria, the evaluators selected 18 articles for this review. The flowchart is shown in Figure 1.

The classification of the level of evidence was performed using the Center for Evidence-Based Medicine (CEBM) model at the University of Oxford ${ }^{(23)}$. The classification for the level of evidence of this methodology is based on degrees of recommendation, which are: A (1A: Systematic Reviews of Controlled and Randomized Clinical Trials; 1B: Controlled and Randomized Clinical Trial with Narrow Confidence Interval; 1C:Therapeutic Results "all or nothing"type); B (2A: Systematic Review with Homogeneity of Cohort Studies; 2B: Cohort Study - Including Lesser Randomized Clinical Trial; 2C: Observation of Therapeutic Results and Ecological Study; 3A: Systematic Review with Homogeneity of Case-Control Studies; 3B: Case-Control Study), C (4: Case Reports - including lower quality Cohort or Case-Control) and D (5: Opinion without critical assessment or based on basic materials - physiological study or study with animals).

Assessment is by type of study and the closer to score 1 is categorized, the greater the level of evidence and degree of recommendation.

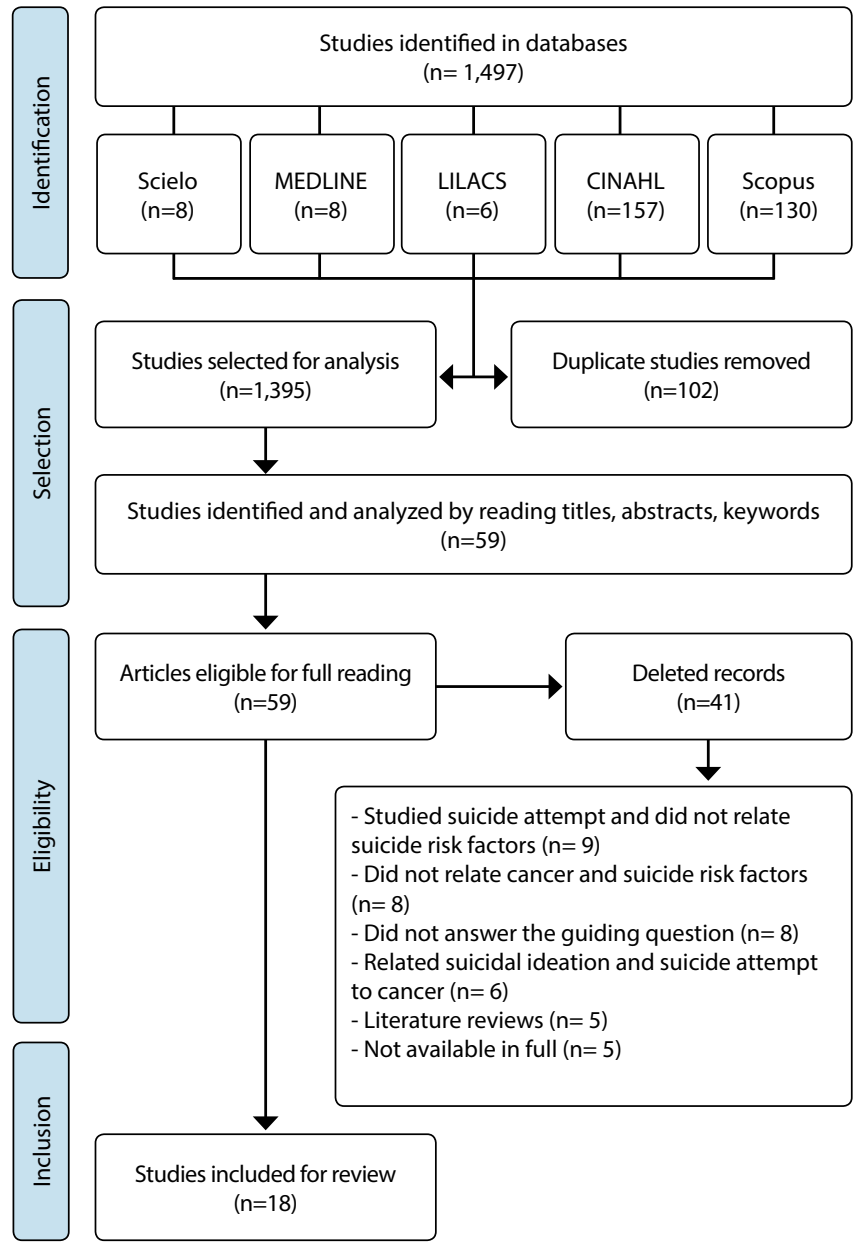

Figure 1 - Flowchart per step of the selection of scientific articles

\section{RESULTS}

Of the total of 18 articles selected on suicide in cancer patients, cohort studies were predominant, with 17 articles, and only one was a case-control study. In this regard, the level of evidence most frequently categorized was 2B, for the 17 cohort articles, and the case-control study was categorized with level of evidence 3B (Chart 2).

Chart 2 - Synthesis of articles selected in the review according to year of publication, authorship, country of study, type of study, objective, and level of evidence

\begin{tabular}{|c|c|c|c|}
\hline Author/Year & $\begin{array}{l}\text { Country/Type of study/ } \\
\text { Sample }\end{array}$ & Objective & $\begin{array}{l}\text { Level of } \\
\text { evidence }\end{array}$ \\
\hline Oberaigner, Sperner-Unterweger, Fiegl et al. (2014) ${ }^{(24)}$ & Austria/Cohort ( $\mathrm{n}=231)$ & $\begin{array}{l}\text { To investigate the risk of suicide in cancer patients } \\
\text { compared to the general population. }\end{array}$ & $2 \mathrm{~B}$ \\
\hline Ahn, Lee, Ramsey et al. (2015) ${ }^{(14)}$ & $\begin{array}{l}\text { South Korea/Case-control }(\mathrm{n} \\
\text { cases }=373 / \mathrm{n} \text { controls }=746)\end{array}$ & $\begin{array}{l}\text { To determine suicide risk factors in the first year of cancer } \\
\text { diagnosis. }\end{array}$ & 3B \\
\hline Klaassen, Jen, DiBianco et al. $(2015)^{(25)}$ & USA/Cohort ( $n=794)$ & $\begin{array}{l}\text { To identify factors associated with suicide in patients with } \\
\text { genitourinary neoplasms. }\end{array}$ & $2 B$ \\
\hline Sugawara, Kunieda (2016) ${ }^{(26)}$ & USA/Cohort $(n=23,620)$ & $\begin{array}{l}\text { To identify factors associated with increased risk of suicide } \\
\text { in cancer patients. }\end{array}$ & $2 B$ \\
\hline Jayakrishnan, Sekigami, Rajeev et al. (2017) ${ }^{(27)}$ & USA/Cohort $(n=631,364)$ & To analyze the risk of suicide in patients with solid cancer. & 2B \\
\hline Siracuse, Gorgy, Ruskin et al. (2017) ${ }^{(28)}$ & USA/Cohort $(n=23,620)$ & $\begin{array}{l}\text { To determine the incidence of suicide in patients with } \\
\text { bone and soft tissue cancer. }\end{array}$ & 3B \\
\hline Samawi, Shaheen, Tang et al. $(2017)^{(29)}$ & USA/Cohort $(n=1,005,825)$ & $\begin{array}{l}\text { To identify predictors of suicide in patients with colon } \\
\text { cancer vs. rectal cancer. }\end{array}$ & 2B \\
\hline
\end{tabular}


Chart 2 (concluded)

\begin{tabular}{|c|c|c|c|}
\hline Author/Year & $\begin{array}{l}\text { Country/Type of study/ } \\
\text { Sample }\end{array}$ & Objective & $\begin{array}{l}\text { Level of } \\
\text { evidence }\end{array}$ \\
\hline Zendron, Zequi, Guimarães, Lourenço $(2018)^{(30)}$ & Brasil/Cohort $(n=144)$ & $\begin{array}{l}\text { To determine the risk of suicide in patients diagnosed with } \\
\text { prostate cancer. }\end{array}$ & 2B \\
\hline Klaassen, Goldberg, Chandrasekar et al. (2018) & USA/Cohort $(n=915,303)$ & $\begin{array}{l}\text { To characterize patients at risk of suicide after bladder } \\
\text { cancer diagnosis. }\end{array}$ & $2 B$ \\
\hline Gaitanidis, Alevizakos, Pitiakoudis et al. $(2018)^{(32)}$ & USA/Cohort $(n=19,409)$ & $\begin{array}{l}\text { To identify relevant risk factors among breast cancer } \\
\text { patients. }\end{array}$ & $2 B$ \\
\hline Wash, Talukder, Lawson et al. $(2018)^{(33)}$ & USA/Cohort $(n=168,339)$ & $\begin{array}{l}\text { To examine the associated factors in patients with thyroid } \\
\text { cancer. }\end{array}$ & $2 B$ \\
\hline Zhou, Xian, Zhang et al. $(2018)^{(34)}$ & USA/Cohort $(n=5,440)$ & To estimate suicide rate trend in patients with lung cancer. & $2 B$ \\
\hline Yang, He, Chen et al. (2019) ${ }^{(35)}$ & USA/Cohort $(n=90,911)$ & $\begin{array}{l}\text { To identify risk factors for suicide death in male patients } \\
\text { with cancer of the genital system. }\end{array}$ & $2 B$ \\
\hline Guo, Zheng, Zhu et al. (2019) ${ }^{(36)}$ & USA/Cohort $(n=171,819)$ & $\begin{array}{l}\text { To identify the possible risk factors associated with suicide } \\
\text { in kidney cancer. }\end{array}$ & $2 B$ \\
\hline Zaorsky, Zhang, Tuanquin et al. (2019) ${ }^{(37)}$ & USA/Cohort $(n=856,293)$ & $\begin{array}{l}\text { To identify cancer patients at higher risk for suicide } \\
\text { compared to the general population. }\end{array}$ & $2 \mathrm{~B}$ \\
\hline Saad, Gad, Al-Husseini et al. (2019) $)^{(38)}$ & USA/Cohort $(n=4,671,989)$ & $\begin{array}{l}\text { To examine the risk of suicide within a year after a cancer } \\
\text { diagnosis. }\end{array}$ & $2 \mathrm{~B}$ \\
\hline Dulsas, Patasius, Kaceniene et al. (2019) ${ }^{(39)}$ & USA/Cohort $(n=19,409)$ & $\begin{array}{l}\text { To estimate the risk of suicide among patients with } \\
\text { colorectal cancer. }\end{array}$ & $2 \mathrm{~B}$ \\
\hline Henson, Brock, Charnock et al. (2019) & $\begin{array}{l}\text { England/Cohort } \\
(n=4,722,099)\end{array}$ & To quantify the risk of suicide in cancer patients. & $2 B$ \\
\hline
\end{tabular}

Chart 3 - Type of cancer studied in articles and main risk factors for suicide organized by year of publication

\begin{tabular}{|c|c|c|}
\hline Reference & Study cancer type & Outcome \\
\hline 24 & All cancers & $\begin{array}{l}\text { 1. All cancers, except non-melanoma skin cancers, were a risk factor for suicide. } \\
\text { 2. Depression and advanced stage of cancer was associated with increased risk of suicide. } \\
\text { 3. Suicide was higher during the first six months after diagnosis. }\end{array}$ \\
\hline 14 & All cancers & $\begin{array}{l}\text { 1. Biliary pancreatic cancer, lung cancer and stomach cancer have more risk of suicide than other types of } \\
\text { cancer. } \\
\text { 2. Metastatic stage was more frequent associated with suicide risk in the first year of diagnosis. }\end{array}$ \\
\hline 25 & $\begin{array}{l}\text { Male genitourinary } \\
\text { cancers: prostate, bladder, } \\
\text { kidney, testis and penis }\end{array}$ & $\begin{array}{l}\text { 1. The genitourinary cancers studied had a significantly statistical risk for suicide. } \\
\text { 2.Males, over } 60 \text { years old, single, white, metastatic disease and non-committing to surgery were risk factors for } \\
\text { suicide. } \\
\text { 3. Pain, penis mutilation and erectile dysfunction were risk factors for suicide in individuals with cancer. }\end{array}$ \\
\hline 26 & Stomach cancer & $\begin{array}{l}\text { 1. Individuals with stomach cancer have a four-fold higher risk of suicide compared to the general population. } \\
\text { 2. The risk of suicide is higher in the first three months after diagnosis. } \\
\text { 3.Male, white, single and metastatic disease are significantly associated with increased risk of suicide. }\end{array}$ \\
\hline 27 & $\begin{array}{l}\text { All cancers except } \\
\text { leukemia }\end{array}$ & $\begin{array}{l}\text { 1. Individuals undergoing advanced stage cancer surgery, males and age older than } 65 \text { years were factors } \\
\text { significantly associated with suicide risk. } \\
\text { 2. The time of greatest involvement of suicide was in the first month. }\end{array}$ \\
\hline 28 & Soft tissue sarcoma & $\begin{array}{l}\text { 1. Bone and soft tissue cancer are associated with suicide risk, especially those of the spine and pelvic bones. } \\
\text { 2. Males, white and older than } 60 \text { years were risk factors for suicide. } \\
\text { 3. The risk of suicide was present in the first five years of diagnosis and mutilation and loss of functionality } \\
\text { increased the risk for suicide. }\end{array}$ \\
\hline 29 & Colorectal cancer & $\begin{array}{l}\text { 1. Colon cancer is a risk factor for suicide. } \\
\text { 2. Males, older than } 60 \text { years, white, metastatic disease and not having undergone surgical procedure were } \\
\text { predictors of suicide. }\end{array}$ \\
\hline 30 & Prostrate cancer & $\begin{array}{l}\text { 1. Prostate cancer was a suicide risk factor. } \\
\text { 2. The risk of suicide was associated with anxiety, depression, singles and living alone. }\end{array}$ \\
\hline 31 & Bladder cancer & $\begin{array}{l}\text { 1. Bladder cancer was a risk factor for suicide. } \\
\text { 2. Males, white, single, older than } 60 \text { years, non-metastatic disease and not submitted to surgical procedure } \\
\text { were risk factors for suicide. }\end{array}$ \\
\hline 32 & Breast cancer & $\begin{array}{l}\text { 1. Breast cancer was a risk factor for suicide. } \\
\text { 2. Males, age under } 60 \text { years, white and black and single were risk factors for suicide. } \\
\text { 3. Until the second year after cancer diagnosis, there was a significant association with suicide. }\end{array}$ \\
\hline 33 & Thyroid cancer & 1. Males and white were risk factors for suicide in thyroid cancer. \\
\hline
\end{tabular}


Chart 3 (concluded)

\begin{tabular}{|c|c|c|}
\hline Reference & Study cancer type & Outcome \\
\hline 34 & Lung cancer & $\begin{array}{l}\text { 1. Individuals with lung cancer are at risk for suicide. } \\
\text { 2. Males, white, single and age over } 60 \text { years were risk factors for suicide. }\end{array}$ \\
\hline 35 & All cancers for males & $\begin{array}{l}\text { 1. Cancer diagnosis is associated with increased risk of suicide. } \\
\text { 2. Over } 60 \text { years of age, single, white and not having undergone surgical procedure were a risk for suicide. } \\
\text { 3.The first year after diagnosis has an increased risk of suicide. }\end{array}$ \\
\hline 36 & Kidney cancer & $\begin{array}{l}\text { 1. Kidney cancer was a risk factor for suicide. } \\
\text { 2.Male, single, white color, advanced disease and not having surgery were risk factors for suicide. } \\
\text { 3. Pain increased risk of suicide in individuals with kidney cancer. }\end{array}$ \\
\hline 37 & All cancers & $\begin{array}{l}\text { 1. Lung, head and neck, testicle, bladder, and lymphoma cancers were at higher risk for suicide compared to } \\
\text { other cancers. } \\
\text { 2. Males, white, age over } 60 \text { years and local disease were risk factors for suicide. }\end{array}$ \\
\hline 38 & All cancers & $\begin{array}{l}\text { 1. Pancreatic, lung and colorectal cancer presented a higher risk for suicide. } \\
\text { 2. The first year after diagnosis was at higher risk for suicide. }\end{array}$ \\
\hline 39 & Colorectal cancer & $\begin{array}{l}\text { 1. Colorectal cancer was a risk factor for suicide. } \\
\text { 2. Females, age older than } 60 \text { years and advanced stage of cancer were risk factors for suicide. } \\
\text { 3. Colostomy increased the risk of suicide in individuals with colorectal cancer. }\end{array}$ \\
\hline 40 & All cancers & $\begin{array}{l}\text { 1. Cancer diagnosis carries a risk of psychological distress. } \\
\text { 2. Individuals with mesothelioma have a higher risk compared to other cancers for suicide. } \\
\text { 3. Pancreatic, esophagus, lung and stomach cancer posed a risk to suicide. } \\
\text { 4. The first six months after diagnosis presented a higher risk for suicide. }\end{array}$ \\
\hline
\end{tabular}

Of the total of 18 articles analyzed, five reported results in the broad category of cancers ${ }^{(14,24,37-38,40)}$. Among these studies, the type of cancer with the highest risk for suicide was lung cancer, observed in four articles ${ }^{(14,37-38,40)}$.

Eight articles verified the risk of suicide after cancer diagnosis, the period of time being identified as being the most at risk: first month $^{(27)}$, third month ${ }^{(26)}$, sixth month ${ }^{(24)}$, first year ${ }^{(14,35,38)}$, second year ${ }^{(32)}$ and up to five years ${ }^{(28)}$ after diagnosis.

For individuals with cancer who committed suicide, the profile shown in the articles was male, white and older than 60 years ${ }^{(25-29,31-37)}$. Being single was also associated with increased risk of suicide in seven studies ${ }^{(25-26,30,32,34-36)}$.

Anxiety and depression were associated with suicide in two studies $^{(24,30)}$. Advanced cancer appeared in six articles associated with an increased risk of suicide ${ }^{(14,24-27,29)}$. There was evidence in five articles that when cancer is not operable or there is a surgical refusal, individuals were also at risk for suicide $25,29,31,35-36)$.

The results of the selected articles are shown in Chart 3.

\section{DISCUSSION}

This review made it possible, through the search for current scientific articles, to know the main risk factors associated with cancer and suicide. Most studies carried out presented a cohort design ( $n=17)$. The cohort research design is adequate to study the risk factors for having statistical analyzes that can infer possible risks for suicide in individuals with cancer ${ }^{(41)}$.

The risk of suicide, in this review, was associated with the site of cancer, such as lung cancer ${ }^{(14,37-38,40)}$, bladder cancer ${ }^{(25,31,35)}$ and colorectal cancer ${ }^{(29,39)}$, although considering that some articles studied specific types of cancer. The reason why cancer, particularly one with a poor prognosis, increases the risk of suicide is probably multifactorial(42). In a cohort carried out in South Korea, it was observed that the risk of suicide was associated with the anatomical site of the cancer, with the risk being increased in cancers with poor prognosis, such as biliary, pancreatic, and pulmonary ${ }^{(14)}$. This is consistent with studies that found that cancer patients with a poor prognosis (i.e., a relative 5-year survival of less than $10 \%$ ) had the highest risk of death from suicide, within one year after diagnosis ${ }^{(13-14,16)}$.

Studies have shown that when diagnosed with lung cancer, the risk of suicide is associated with aggressive treatment and with no prospect of a cure just for symptom palliation ${ }^{(14,37-38,40)}$. It is necessary to pay more attention to this type of cancer, as it is evidenced as the one most prone to suicide ${ }^{(24)}$. For genitourinary cancers, risk factors were associated with symptoms such as urinary incontinence, pain during intercourse and erectile dysfunction ${ }^{(25,31)}$. The same was observed in one about prostate cancer, because, in addition to the symptoms, there were individuals who refused treatment and surgical procedure, thus facing a greater risk of suicide ${ }^{(43)}$.

Surgical therapy makes individuals with cancers more vulnerable to suicide, as mutilation is also a risk factor ${ }^{(25,27)}$. Articles on colorectal cancer showed that surgical resection of the colon and colostomy bag were factors for suicide ${ }^{(29,39)}$. This data was similar to a study carried out in patients with osteosarcoma, who are submitted to extensive surgical resections and even limb mutilation ${ }^{(28)}$. It was observed that, after surgery, individuals who had changes in gait, strength and a mutilated limb were at higher risk of suicide ${ }^{(28)}$.

Time of suicide after cancer diagnosis was studied in eight articles in this integrative review ${ }^{(14,26-28,32,35,38)}$. The first three months of knowledge of the disease was possibly associated with difficulty of coping, its symptoms and adverse effects of treatment ${ }^{(26-27)}$. Another study, in turn, showed that from the sixth month onwards, the risk of suicide was associated with the stage of cancer. A cohort study carried out in Tyrol, Austria, showed that a quarter of suicides occurred in the first six months, in patients with advanced cancer stage $^{(24)}$. In another cohort study, it was found that more than $70 \%$ of suicides in the first year occurred in patients with metastatic stages, but the risk decreases over time, with no difference between individuals with cancer and the general population ${ }^{(14)}$. This 
data was different from that found in a North American cohort, in which there was a risk of suicide after five years of diagnosis ${ }^{(28)}$. The authors related that the factor for this suicide risk was the presence of pain, hopelessness, and depression ${ }^{(25,28,36)}$. More than a cultural aspect, the poor prognosis of a disease, in addition to the adverse effects of treatment, makes individuals with cancer dependent on another person, such as a family member ${ }^{(19)}$.

Male, white and old age were risk factors for suicide in individuals with cancer, as found in twelve articles ${ }^{(25-29,31-37)}$. Increased risk of suicide for men due to cancer was related to socioeconomic situations, as men end up moving away from work, reducing family income ${ }^{(19-20,24)}$. Another study showed that the feelings of demoralization, helplessness and hopelessness are greater among males, which can lead to suicide ${ }^{(34)}$. Another cohort study showed that men also tend to seek less family support or live alone, which makes it difficult to form a help network so that individuals can support cancer diagnosis and treatment ${ }^{(30)}$. Two studies have shown that a form of guidance for the reduction of suicides is through support groups, as they strengthen the health network and assist services in preventing suicide ${ }^{(24,27)}$.

This review noticed that depression was associated with a risk factor for suicide in two studies ${ }^{(24,30)}$. Depression is a significant risk factor for suicide in individuals with cancer $^{(30)}$. The verified relationship between depression and suicide is manifested in symptoms, both physical, such as pain, and in subjective symptoms, such as changes in mood and financial situation ${ }^{(28-29)}$. Two cohorts, one from England and one from the United States, have shown that the immediate health implications of cancer survivors are legitimate financial burdens, which can cause depression and increase the risk of suicide ${ }^{(36,40)}$. One study found that the relationship between suicide in individuals with cancer and depression was the perception or assumption that there is no cure for the disease, increasing the risk of committing suicide ${ }^{(24)}$. Psychotherapy is an important strategy for suicide prevention in individuals who have been diagnosed with cancer ${ }^{(44)}$. A study has shown that psychotherapy has a positive effect on cancer patients, which include symptom control, such as pain relief, disease acceptance and coping ${ }^{(45)}$.

\section{Study limitation}

This study has some limitations: the searches were made in five databases (SciELO, MEDLINE, LILACS, CINAHL and Scopus) and, eventually, other publications may not have been found; the criteria for inclusion of articles in Portuguese and English may have limited access to other publications; some of the selected studies may have bias, because they did not study patients with different types, but with certain types of cancer, such as lung, genitourinary, solid tumors. Thus, it is not possible to conclude that one of the risk factors for suicide is having a certain type of cancer; although the purpose of the integrative review is to show current data, based on primary studies, the studies analyzed were heterogeneous in terms of samples, demographic characteristics and types of cancer, which limited their comparability.

\section{Contributions to nursing, health, and public policies}

Although it is a relatively rare event, healthcare professionals should be aware that cancer diagnosis increases the risk of suicide. In this regard, this study has contributions for nursing professionals, as it outlines the main risk factors for suicide in individuals with cancer. Types of cancer, time of diagnosis and demographic factors most likely to commit suicide in individuals with cancer are explained. The increased risk of suicide in the first six months after cancer diagnosis, pointed out by some of the studies in this review, suggests the need for psychosocial support and support and special attention for individuals with specific cancer groups. Nurses are the health professionals who most stay with patients with cancer, thus being able to recognize suicidal ideation and behavior. Carrying out systematic screening to identify suicidal ideation and behavior allows an individual with cancer, who presents a risk of suicide, to be evaluated and the appropriate mental health treatment performed.

\section{CONCLUSION}

The present integrative review made it possible to verify that cancer can predispose suicide to individuals affected by this disease. Identifying cancer, demographic characteristics, the time from diagnosis to suicide and the adverse effects left by cancer such as pain and loss of functionality guide health professionals to be attentive in care practice. Based on what was verified in this study, the evidence can be useful for planning preventive actions, in order to reduce the risk of suicide.

\section{FUNDING}

This study was financed in part by the Coordenação de Aperfeiçoamento de Pessoal de Nível Superior - Brazil (CAPES) - Finance Code 001

\section{REFERENCES}

1. Zhu J, Xu L, Sun L, Li J, Qin W, Ding G, et al. Chronic disease, disability, psychological distress and suicide ideation among rural elderly: results from a population survey in Shandong. Int J Environ Res Public Health. 2018;15(8):1604. https://doi.org/10.3390/ijerph15081604

2. Klonsky ED, May AM, Saffer BY. Suicide, suicide attempts, and suicidal ideation. Annu Rev Clin Psychol. 2016;12(1):307-30. https://doi. org/10.1146/annurev-clinpsy-021815-093204

3. Kielan A, Cieślak I, Skonieczna J, Olejniczak D, Jabłkowska-Górecka K, Panczyk M, et al. Analysis of the opinions of adolescents on the risk factors of suicide. Psychiatr Pol. 2018;52(4):697-705. https://doi.org/10.12740/PP/OnlineFirst/78257

4. Sinyor M, Tse R, Pirkis J. Global trends in suicide epidemiology. Curr Opin Psychiatry. 2017;30(1):1-6. https://doi.org/10.1097/YCO.0000000000000296 
5. Ribas JJ, Rolim A, Ciquinato G, Oliveira AA, Perfeito R. Causas da aposentadoria por invalidez de servidores públicos. J Nurs Health. 2017;7(3):1-8. https://doi.org/https://doi.org/10.15210/jonah.v7i3.10290

6. Bray F, Colombet M, Mery L, Piñeros M, Znaor A, Zanetti R, et al. Cancer Incidence in Five Continents [Internet]. Vol. XI. Lyon: Int Agency Res Cancer; 2017 [cited 2019 Oct. 20]. Available from: http://ci5.iarc.fr

7. Instituto Nacional de Câncer José Alencar Gomes da Silva. Estimativa 2020: incidência de câncer no Brasil. Rio de Janeiro: INCA; 2019.120 p.

8. Vehling S, Kissane DW, Lo C, Glaesmer H, Hartung TJ, Rodin G, et al. The association of demoralization with mental disorders and suicidal ideation in patients with cancer. Cancer. 2017;123(17):3394-401. https://doi.org/10.1002/cncr.30749

9. Zhang X, Zhang J, Procter N, Chen X, Su Y, Lou F, et al. Suicidal ideation and psychological strain among patients diagnosed with stomach cancer. J Nerv Ment Dis. 2017;205(7):550-7. https://doi.org/10.1097/NMD.0000000000000679

10. Amiri S, Behnezhad S. Cancer diagnosis and suicide mortality: a systematic review and meta-analysis. Arch Suicide Res. 2019;1-19. https:// doi.org/10.1080/13811118.2019.1596182

11. Chochinov HM. Depression in cancer patients. Lancet Oncol. 2001;2(8):499-505. https://doi.org/10.1016/s1470-2045(01)00456-9

12. Nasseri K, Mills PK, Mirshahidi HR, Moulton LH. Suicide in cancer patients in California, 1997-2006. Arch Suicide Res. 2012;16(4):324-33. https://doi.org/10.1080/13811118.2013.722056

13. Kye SY, Park K. Suicidal ideation and suicidal attempts among adults with chronic diseases: A cross-sectional study. Compr Psychiatry. 2017;73:160-7. https://doi.org/10.1016/j.comppsych.2016.12.001

14. Ahn MH, Park S, Lee HB, Ramsey CM, Na R, Kim SO, et al. Suicide in cancer patients within the first year of diagnosis. Psychooncol. 2015;24(5):601-7. https://doi.org/10.1002/pon.3705

15. Yamauchi $T$, Inagaki $M$, Yonemoto $N$, Iwasaki $M$, Inoue $M$, Akechi $T$, et al. Death by Suicide and other externally caused injuries after stroke in Japan (1990-2010). Psychosom Med. 2014;76(6):452-9. https://doi.org/10.1097/PSY.0000000000000079

16. Lu D, Fall K, Sparén $\mathrm{P}$, Ye W, Adami H-O, Valdimarsdóttir U, et al. Suicide and suicide attempt after a cancer diagnosis among young individuals. Ann Oncol. 2013;24(12):3112-7. https://doi.org/10.1093/annonc/mdt415

17. Scaini G, Quevedo J. Suicide rates in the United States continue to rise: are rates in Brazil underestimated? Rev Bras Psiquiatr. 2018;40(4):3478. https://doi.org/10.1590/1516-4446-2018-4004

18. Kye SY, Kwon JH, Park K. Happiness and health behaviors in South Korean adolescents: a cross-sectional study. Epidemiol Health. 2016;38:17. https://doi.org/10.4178/epih.e2016022

19. McFarland DC, Walsh L, Napolitano S, Morita J, Jaiswal R. Suicide in patients with cancer: identifying the risk factors. Oncol (US) [Internet]. 2019 [cited 2020 Jan. 12];33(6):221-6. Available from: https://www.cancernetwork.com/view/ oral-apixaban-may-be-safe-alternative-to-subcutaneous-enoxaparin-for-thromboprophylaxis

20. Granek L, Nakash O, Ariad S, Chen W, Birenstock-Cohen S, Shapira S, et al. From will to live to will to die: oncologists, nurses, and social workers identification of suicidality in cancer patients. Support Care Cancer. 2017;25(12):3691-702. https://doi.org/10.1007/ s00520-017-3795-4

21. Valente SM. Oncology nurses' knowledge of suicide evaluation and prevention. Cancer Nurs. 2010;33(4):290-5. https://doi.org/10.1097/ NCC.0b013e3181cc4f33

22. Whittemore R, Knafl K. The integrative review: updated methodology. J Adv Nurs. 2005;52(5):546-53. https://doi. org/10.1111/j.1365-2648.2005.03621.x

23. Centre for Evidence-based Medicine. Oxford Centre for Evidence-based Medicine: levels of evidence [Internet]. University of Oxford; 2009 [cited 2020 Jan. 21]. Available from: http://www.cebm.net/oxford-centre-evidence-based-medicine-levels-evidence-march-2009

24. Oberaigner W, Sperner-Unterweger B, Fiegl M, Geiger-Gritsch S, Haring C. Increased suicide risk in cancer patients in Tyrol/Austria. Gen Hosp Psychiatry. 2014;36(5):483-7. https://doi.org/10.1016/j.genhosppsych.2014.05.017

25. Klaassen Z, Jen RP, DiBianco JM, Reinstatler L, Li Q, Madi R, et al. Factors associated with suicide in patients with genitourinary malignancies. Cancer. 2015;121(11):1864-72. https://doi.org/10.1002/cncr.29274

26. Sugawara A, Kunieda E. Suicide in patients with gastric cancer: a population-based study. Jpn J Clin Oncol. 2016;46(9):850-5. https://doi. org/10.1093/jjco/hyw075

27. Jayakrishnan TT, Sekigami Y, Rajeev R, Gamblin TC, Turaga KK. Morbidity of curative cancer surgery and suicide risk. Psychooncol. 2017;26(11):1792-8. https://doi.org/10.1002/pon.4221

28. Siracuse BL, Gorgy G, Ruskin J, Beebe KS. What is the incidence of suicide in patients with bone and soft tissue cancer? Clin Orthop Relat Res. 2017;475(5):1439-45. https://doi.org/10.1007/s11999-016-5171-y

29. Samawi HH, Shaheen AA, Tang PA, Heng DYC, Cheung WY, Vickers MM. Risk and predictors of suicide in colorectal cancer patients: a surveillance, epidemiology, and end results analysis. Curr Oncol. 2017;24(6):513-7. https://doi.org/10.3747/co.24.3713

30. Zendron $\mathrm{M}$, Zequi S, Guimarães $\mathrm{G}$, Lourenço M. Assessment of suicidal behavior and factors associated with a diagnosis of prostate cancer. Clinics. 2018;73(9):1-4. https://doi.org/10.6061/clinics/2018/e441

31. Klaassen Z, Goldberg H, Chandrasekar T, Arora K, Sayyid RK, Hamilton RJ, et al. Changing trends for suicidal death in patients with bladder cancer: a 40+ year population-level analysis. Clin Genitourin Cancer. 2018;16(3):206-12. https://doi.org/10.1016/j.clgc.2017.12.016 
32. Gaitanidis A, Alevizakos M, Pitiakoudis M, Wiggins D. Trends in incidence and associated risk factors of suicide mortality among breast cancer patients. Psychooncol. 2018;27(5):1450-6. https://doi.org/10.1002/pon.4570

33. Walsh NJ, Talukder AM, Lawson AG, Komic AX, Bateson BP, Jones AJ, et al. Thyroid malignancy and suicide risk: an analysis of epidemiologic and clinical factors. World J Endocr Surg. 2018;10(2):99-102. https://doi.org/10.5005/jp-journals-10002-1227

34. Zhou H, Xian W, Zhang Y, Chen G, Zhao S, Chen X, et al. Trends in incidence and associated risk factors of suicide mortality in patients with non-small cell lung cancer. Cancer Med. 2018;7(8):4146-55. https://doi.org/10.1002/cam4.1656

35. Yang J, He G, Chen S, Pan Z, Zhang J, Li Y, et al. Incidence and risk factors for suicide death in male patients with genital-system cancer in the United States. Eur J Surg Oncol. 2019;45(10):1969-76. https://doi.org/10.1016/j.ejso.2019.03.022

36. Guo C, Zheng W, Zhu W, Yu S, Ding Y, Wu Q, et al. Risk factors associated with suicide among kidney cancer patients: a surveillance, epidemiology, and end results analysis. Cancer Med. 2019;8(11):5386-96. https://doi.org/10.1002/cam4.2400

37. Zaorsky NG, Zhang Y, Tuanquin L, Bluethmann SM, Park HS, Chinchilli VM. Suicide among cancer patients. Nat Commun. 2019;10(1):207. https://doi.org/10.1038/s41467-018-08170-1

38. Saad AM, Gad MM, Al-Husseini MJ, AlKhayat MA, Rachid A, Alfaar AS, et al. Suicidal death within a year of a cancer diagnosis: a populationbased study. Cancer. 2019;125(6):972-9. https://doi.org/10.1002/cncr.31876

39. Dulskas A, Patasius A, Kaceniene A, Urbonas V, Smailyte G. Suicide risk among colorectal cancer patients in Lithuania. Int J Colorectal Dis. 2019;34(3):555-8. https://doi.org/10.1007/s00384-018-03228-4

40. Henson KE, Brock R, Charnock J, Wickramasinghe B, Will O, Pitman A. risk of suicide after cancer diagnosis in England. JAMA Psychiatr. 2019;76(1):51-60. https://doi.org/10.1001/jamapsychiatry.2018.3181

41. Jokinen J, Mattsson F, Lagergren K, Lagergren J, Ljung R. Suicide attempt and future risk of cancer: a nationwide cohort study in Sweden. Cancer Causes Control. 2015;26(3):501-9. https://doi.org/10.1007/s10552-015-0528-1

42. Simpson WG, Klaassen Z, Jen RP, Hughes WM, Neal DE, Terris MK. Analysis of suicide risk in patients with penile cancer and review of the literature. Clin Genitourin Cancer. 2018;16(2):e257-61. https://doi.org/10.1016/j.clgc.2017.09.011

43. Dalela D, Krishna N, Okwara J, Preston MA, Abdollah F, Choueiri TK, et al. Suicide and accidental deaths among patients with non-metastatic prostate cancer. BJU Int. 2016;118(2):286-97. https://doi.org/10.111/bju.13257

44. Rosa GS, Andrades GS, Caye A, Hidalgo MP, Oliveira MAB, Pilz LK. Thirteen Reasons Why: The impact of suicide portrayal on adolescents' mental health. J Psychiatr Res. 2019;108:2-6. https://doi.org/10.1016/j.jpsychires.2018.10.018.

45. Okuyama T, Akechi T, Mackenzie L, Furukawa TA. Psychotherapy for depression among advanced, incurable cancer patients: a systematic review and meta-analysis. Cancer Treat Rev. 2017;56(11):16-27. https://doi.org/10.1016/j.ctrv.2017.03.012 